Article

\title{
Youngsters' Opinions and Attitudes toward the Use of Electric Bicycles in Israel
}

\author{
Wafa Elias ${ }^{1, *}$ and Victoria Gitelman ${ }^{2}$ \\ 1 Shamoon College of Engineering, Jabotinsky str. 84, Ashdod 77245, Israel \\ 2 Transportation Research Institute, Technion City, Haifa 32000, Israel; trivica@technion.ac.il \\ * Correspondence: wafate@walla.com
}

Received: 28 September 2018; Accepted: 16 November 2018; Published: 22 November 2018

check for updates

\begin{abstract}
Throughout Israel, unlike other countries, a growing use of electric bicycle (EB) by youngsters (below 18) has been observed, accompanied by a drastic increase in the number of related injuries. This phenomenon is widely discussed by various authorities and media in Israel, whilst its characteristics are actually unknown. Existing literature on the use of EBs is limited. Thus, an opinion survey of young EB riders was conducted, with the aim of recording and analyzing the characteristics and general perception of teen EB users and to explore their behaviors. The results show that using EBs increases the frequency and the distance of teens' daily commute. The use of EB improves mobility independence, allowing for less reliance on parents and a widening of potential destinations. In addition, the results indicate that a substantial percent of the teens are not familiar with the legal regulations concerning EBs having been involved in various dangerous behaviors. Though the overall preference is to use bicycle paths, the common acceptable alternative is pedestrian sidewalks. These results suggest that a combination of road safety education and training with an improvement of existing infrastructure are the best way to tackle this new and widespread phenomenon.
\end{abstract}

Keywords: e-bicycles; youngsters; behaviors; attitudes; risks

\section{Introduction}

Over the last decade, a rapid increase in the use of electric power-assisted bicycles (also known as e-bicycles, e-bikes or pedelec; hereafter EB) throughout the world and in Israel has been observed. According to the Free Import Order (2011) in Israel, electric bicycles are defined as bicycles with two-wheels composed one after the other and fitted with an electric engine.

According to global estimates, the electric bicycle sales in the world were over 40 million units in 2015, of which 36.8 million (91.9\%) were sold in China and over 2.3 million (5.8\%) in Europe [1]. The number of electric bicycles is rapidly rising in Europe: Between the years 2011-2015 the total amount of sales increased by $88 \%$ [1]. In countries, such as Austria and Germany, the sales of e-bicycles have doubled from 2010 to 2012, while in Switzerland the sales increased by 50\% and in Italy and France by $20 \%$ [2]. Germany and the Netherlands are the leading EB markets, accounting for $44 \%$ and $21 \%$, respectively, of the total European Union sales [1].

Electric bicycles (EB) provide a long-term, inexpensive and convenient form of private mobility in urban areas, being an attractive alternative to private cars, public transport, regular cycling and walking. A quick search on a popular Israeli price comparison website [3] shows a price range for EB between $\$ 570$ and $\$ 7520$. Though this is a wide range, taking into consideration the average monthly salary in Israel being approximately \$2700 [4] and that the cheapest mini-compact car starting at $\$ 13,550$ and a compact family car starting at $\$ 30,000$ [5], it is fair to say that EBs are a substantially cheaper transportation vehicle. Another aspect that makes EBs attractive is their reliance on electricity 
and not gas, the former being much cheaper in Israel (charging an average size battery costs less than 0.15 USD while the price of gasoline is $\$ 6.29$ per gallon) (With batteries ranging between low supplies of $24 \mathrm{v} / 8 \mathrm{ah}$ and high supplies of 36v/10ah, all being less than 0.5 a Kilowatt per hour. Electricity costs in Israel according to the Israel Electric Company true to 2018 was 0.54 NIS, with an exchange with the USD of $\$ 1=3.72$, making it less than $\not 15$.) $[6,7]$. Electric assistance to the rider reduces the physical efforts required for riding. Therefore, EBs are associated with a potential to expand the role of cycling in urban transport [8].

Studies show that the durations and distances of travels performed by EB riders increase compared to travels on conventional bicycles and that EBs often replace private car travels for daily purposes $[9,10]$. In addition, EBs are useful for people that are not able to ride conventional bicycles, due to physical limitations [11].

To ride on electric bicycles, typically there is no need for a driving license, vehicle license or insurance, similarly to conventional bicycles. In different countries, EB-related regulations usually deal with the limitations on maximum power of the EB engine and maximum permitted travel speeds. Having reached the maximum speed (which is typically $25 \mathrm{kph}$ ), the EB engine should stop its operation [8]. In some countries, like Israel and Great Britain, there is an age limit for EB riding (14 years old in the UK, currently 16 in Israel).

Studies have found that EB users are mainly men, aged 30 and above, with higher income and education levels compared with users of conventional bicycles [12,13]. In Israel, unlike other countries, there is a high share of youngsters riding EBs-teenagers below the age of 18, some of them younger than 16. Young EB riders can be seen on sidewalks, roads, bicycle routes and junctions, especially during the morning and afternoon school rush, where some of them ride at seemingly high speeds [13].

According to traffic regulations in Israel [14], only people aged 16 and above are allowed to ride electric bicycles. Previously, before May 2016, a person over the age of 14 was permitted to ride an EB, but strictly on bicycle lanes, whereas a person over the age of 16 was permitted to ride it also on roads. Today, e-cyclists are allowed to ride on bicycle facilities and on roads, but are prohibited to ride on sidewalks, crosswalks or other pedestrian areas. In urban areas, wearing a helmet is mandatory for cyclists under the age of 18 . A rider is permitted to carry another person only if the EB is fitted for carrying, i.e., has more than one seat.

There are various media reports in Israel stating that on urban streets, mainly in the center [15-17] of the country, young e-bicycle users ride recklessly, ignore the traffic regulations, some of them ride at high speeds on sidewalks and disturb pedestrians' movement. This phenomenon is widely discussed by various authorities in Israel, whilst its actual characteristics are unknown.

Empirical studies showed that EB riders usually ride faster than conventional bicycle riders, however, the speed differences are not big. Studies from the USA and Europe demonstrated more safety-careful behaviors of EB users, such as helmet use, compliance with traffic signs and more careful riding on bicycle-shared paths, without considerable differences compared to conventional bicycle riders $[11,18,19]$. However, studies from China, found high rates of traffic violations and dangerous behaviors among EB riders, such as carrying another person on the bike and running red lights [20,21].

Research findings show that the chance of EB riders being involved in conflicts with other road users is higher compared to conventional bicycles, and that the risk of being involved in a conflict increases at intersections, in the proximity of crosswalks and with an increase in riding speeds [22,23]. In addition, the risk of EB riders to be injured or killed in a road accident is higher compared to regular bicycle riders $[9,24]$.

In Israel, in recent years, there has been a drastic increase in the number of injuries due to EB and electric scooters' accidents-with a considerable share of the injured being pedestrians, and a large share of the EB injured were teenagers $[25,26]$.

Being aware of the growing phenomenon of using e-bicycles by youngsters in Israeli towns, with their seemingly dangerous behaviors and already negative implications on road traffic injury, an opinion survey of teen e-cyclists was conducted in this study. The survey aimed to record and 
analyze the characteristics and general perception of teen EB users and to explore the young e-cyclist behaviors, because the literature on e-cyclists' behaviors and perceptions is not extensive, and mostly refer to adults. The following sections of this paper cover methods, results, discussion, and conclusions.

\section{Methodology}

\subsection{Data and Procedure}

The current study is based on an opinion survey that aims to record and analyze how young e-cyclists perceive the scope and future of EB use, EB travel profiles and priorities, the characteristics of EB users, and EB-related risks experienced either personally or as a matter of perceived norms. The survey includes two components: Four focus groups and a closed questionnaire, to be completed by 326 students across the schools examined in the study.

The sample included four schools: Two junior high-schools (grades 7th-9th) and two high-schools (grades 10th-12th). All schools were chosen from within Israel's central region-Kfar Saba, Netanya, and Tel Aviv (two schools) - where e-biking in particular and cycling in general, are considered to be common practices. The headmasters of all four schools granted their approval, and the survey was conducted during November 2016. The questionnaire was distributed in class to all pupils present, who were given 45 mins to respond. After which, all the pupils handed their completed questionnaire, therefore, $100 \%$ of the pupils completed the questionnaire.

The current paper relies exclusively on the results of the closed questionnaire while the focus groups were used as a guideline for developing the closed questionnaire.

The questionnaire was based on recent literature regarding EB, as well as the planned behavior theory [27], which is commonly used to both identify and analyze factors leading to risky behavior. Main themes include: Demographic characteristics, daily activities, travel needs, typical EB routes, stated EB priorities and needs; risk perception.

Statistical data analyses (correlations, regression, clustering, and tests of differences) was applied to describe mobility profiles and priorities, risk perception and self-reported experiences of young EB riders, and to examine their relations to personal characteristics. In addition to estimating the variables that affect the decision to ride EBs, a logistic regression was used in which the dependent variable has two alternatives-riding EBs, or not riding EBs.

\subsection{Main Characteristics of the Sample}

The sample consists of 326 pupils. About half of the participants (49.8\%) were boys and half girls. About $52 \%$ of the participants are under than 16 years old and approximately $34 \%$ were active e-cyclists. Of those, $73 \%$ have used push-bikes before using electric bicycles.

About $51 \%$ of the pupils are from households that own several cars, $38 \%$ have one car, while only $11 \%$ are from households that do not own cars. Approximately one quarter of the pupils, travel abroad once a year, and $13 \%$ travel several times a year. Only $20 \%$ have never traveled abroad. The great majority $(96 \%)$ of the participants own smartphones, therefore, owning a smart-phone cannot be considered a measure for socio-economic standing.

\section{Results}

\subsection{The Use of Electric Bicycles}

We first examined the variation in riding EBs by gender and by age. Figure 1 shows that boys are much more likely to ride EB than girls, while less than one in every five girls (18.7\%) ride EB, approximately one in every two boys $(48.3 \%)$ rides an EB. This difference is statistically significant (using Pearson Chi-Square test, $p<0.000$ ). Teens aged 16 or older are more likely to ride EB than those younger than 16 (Figure 2). This difference in the distribution is statistically significant ( $p$ value $=0.05$ ). 
In addition, $65 \%$ of the pupils who regularly use EB have been riding an EB for over a year. Only 3\% had less than one month of experience (Figure 3).

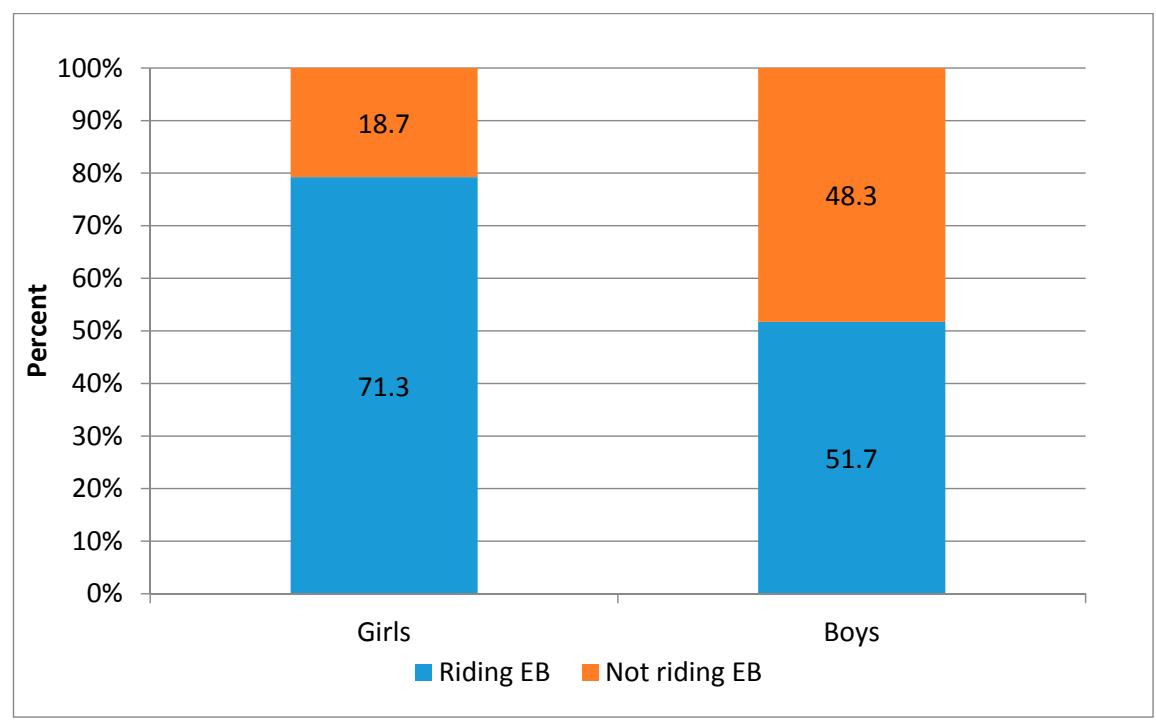

Figure 1. Riding electric power-assisted bicycles (EBs) by gender.

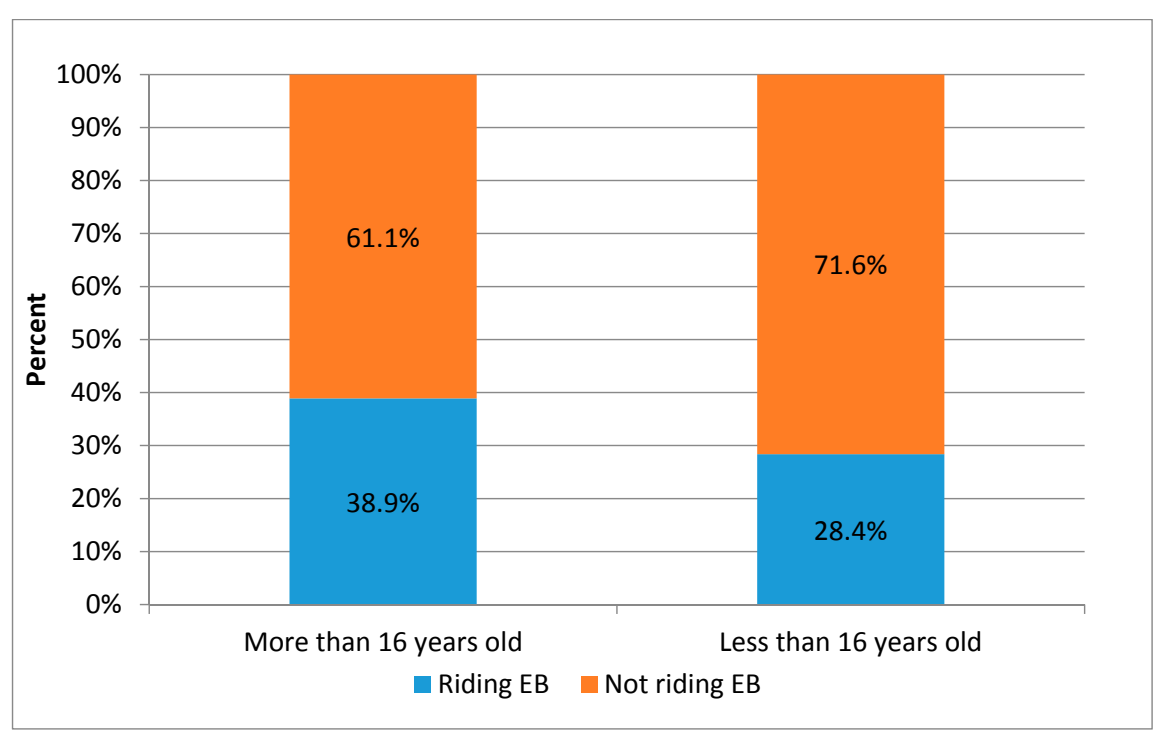

Figure 2. Likelihood of e-biking according to age.

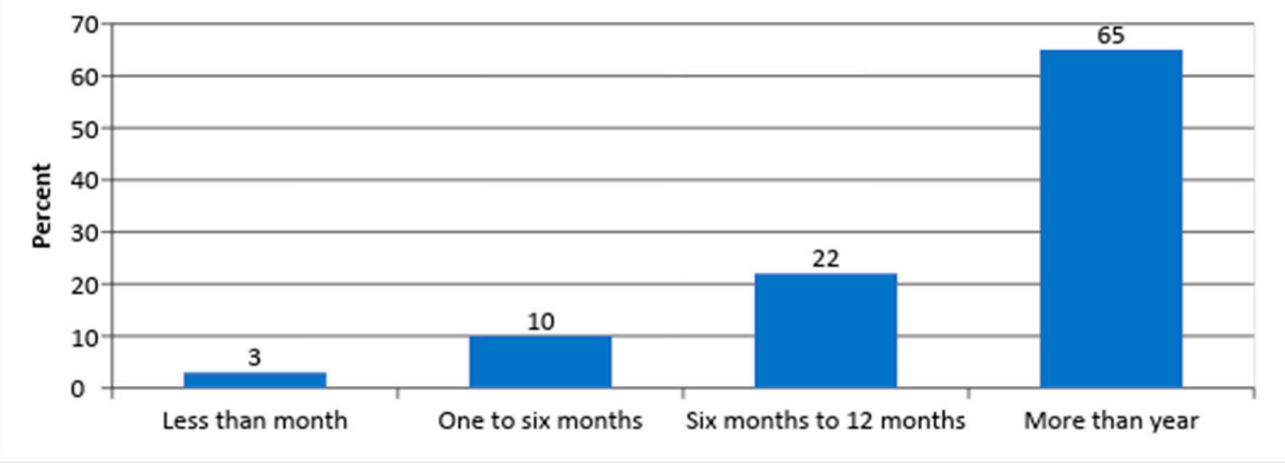

Figure 3. Distributions of pupils riding EBs by level of experience. 
Table 1 shows that EB was the most commonly used mode for all the destinations, and visiting friends was overall the most popular destination.

Table 1. During the last week, what were the main destinations you visited, and which travel mode did you use?

\begin{tabular}{cccccc}
\hline Destination & Walking & $\begin{array}{c}\text { Riding } \\
\text { an EB }\end{array}$ & $\begin{array}{c}\text { Car with } \\
\text { Parents }\end{array}$ & $\begin{array}{c}\text { Bus or Taxi } \\
\text { Service }\end{array}$ & $\begin{array}{c}\text { Total } \\
\text { Number }\end{array}$ \\
\hline School & $3.3 \%$ & $12.5 \%$ & $2.9 \%$ & $1.8 \%$ & 105 \\
Sports center & $1.0 \%$ & $10.1 \%$ & $1.9 \%$ & $0.2 \%$ & 68 \\
Mall/commercial center & $2.3 \%$ & $12.5 \%$ & $3.7 \%$ & $2.5 \%$ & 108 \\
A friend's house & $2.9 \%$ & $15.0 \%$ & $2.5 \%$ & 0 & 105 \\
Park & $3.3 \%$ & $12.4 \%$ & $2.1 \%$ & $0.6 \%$ & 95 \\
Other & $0.4 \%$ & $4.3 \%$ & $1.2 \%$ & $0.6 \%$ & 33 \\
Total number & 68 & 343 & 74 & 29 & 514 \\
\hline
\end{tabular}

For the question about the preferred locations for riding EBs, while the students were asked to rate their preference from 1 to 5 , when 1 did not prefer at all and 5 loved to ride there. Figure 4 shows that over $50 \%$ of the population prefers riding EBs on a bike path. It is interesting to note that about a third (14\%) preferred to ride on the road. In addition, it is unsurprising that children like to ride in parks, with $40 \%$ of the respondents preferring it.

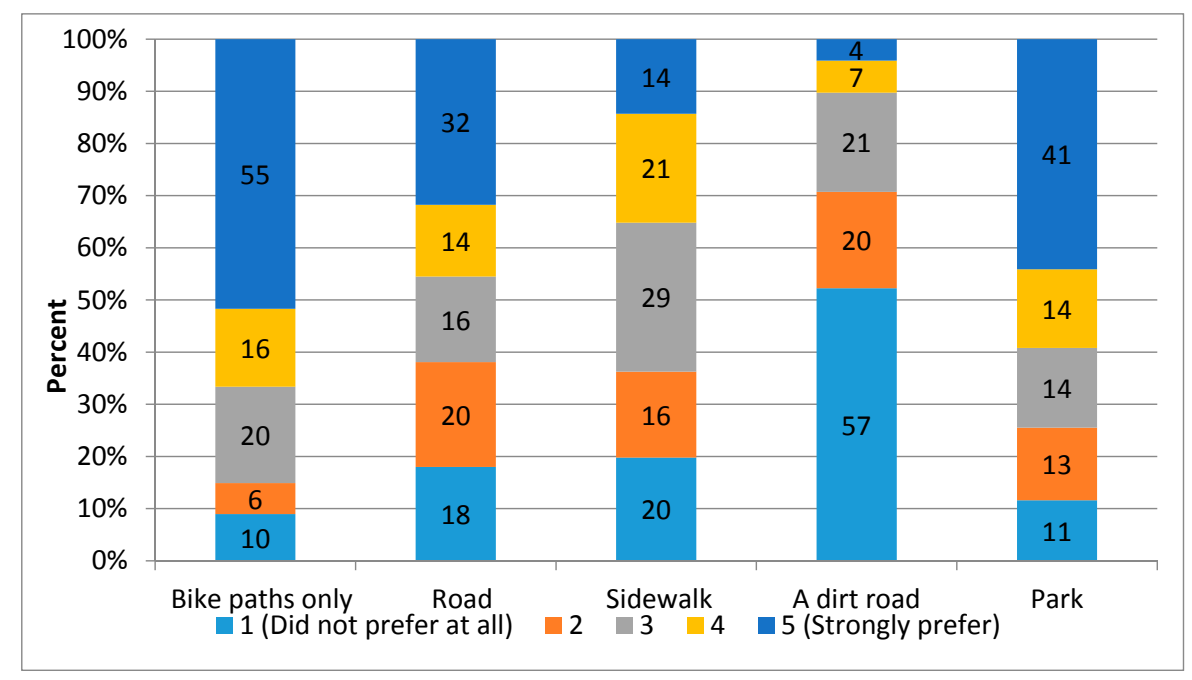

Figure 4. Preferred location for riding EBs.

\subsection{Motivation and Barriers}

Figure 5 presents the main reasons for using EBs. For this question, participants were allowed to choose more than one reason. The two most cited reasons for using EB being able to commute to new destinations without any assistance. Commuting independently to school was the second.

Consistent with previous findings, having EBs increases the number of destinations that pupils frequent. With about $60 \%$ of all pupils indicating that their destinations will 'increase' and 'greatly increase' as a result of using EBs, while only $15 \%$ indicated that EBs do not have too much of an impact (Figure 6). 


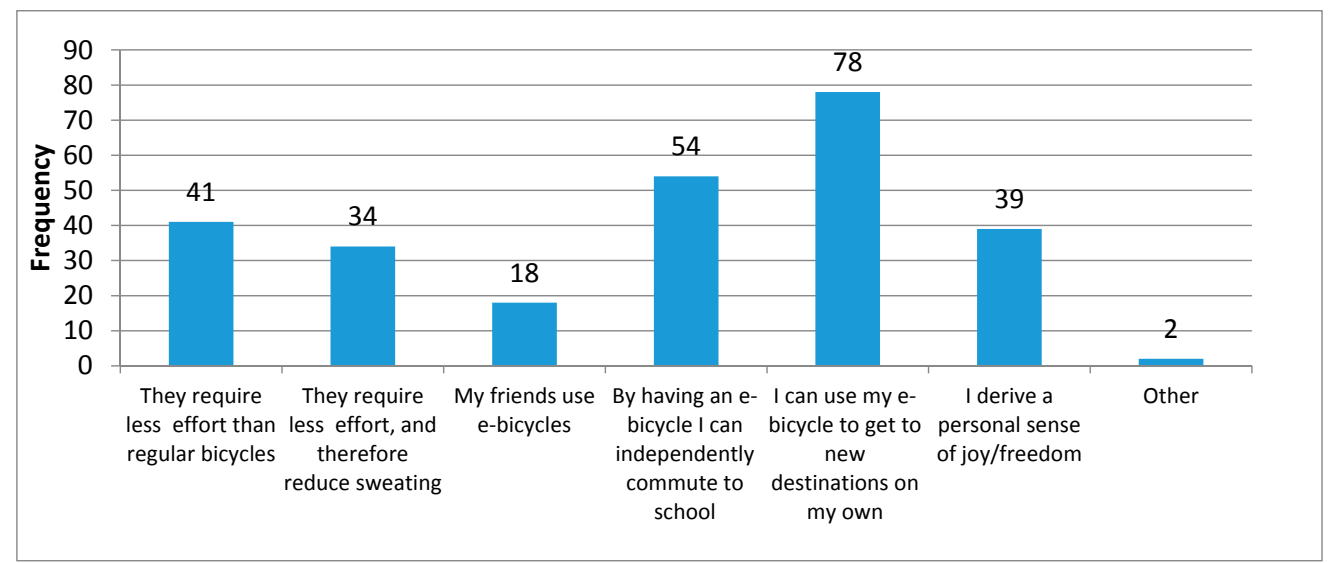

Figure 5. Main reasons for using EBs.

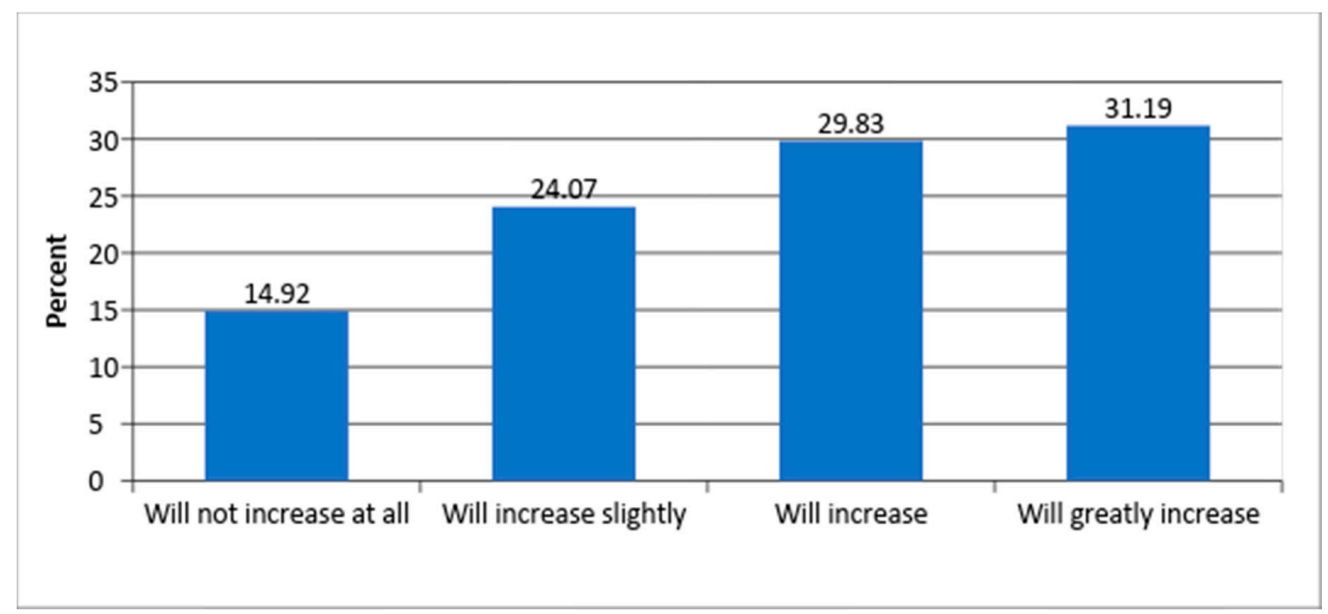

Figure 6. Changes in the number of destinations.

In order to understand which factors deter the pupils from using EBs, we asked them to choose as many options as they want from a given list. Table 2 reflects this list. More than $60 \%$ of the participants admitted they were afraid of being involved in a road accident. The second most popular reason was the high retail price of electric bicycles, followed by parental resistance. Clearly young EB riders are aware of the risks involved in this mode of transportation.

Table 2. Factors that make it difficult for pupils to use an electric bicycle.

\begin{tabular}{lc}
\hline \multicolumn{1}{c}{ Reasons } & Frequency* in \% \\
\hline The high retail price of electric bicycles & 35.6 \\
\hline Riding an electric bicycle is illegal & 20.1 \\
\hline Fear of road accidents & 61.8 \\
\hline Fear of the weight of the bicycle and the difficulty of maneuvering it & 11.5 \\
\hline Fear of being stolen & 23 \\
\hline Lack of bicycle paths for safe riding & 16.5 \\
\hline Parental resistance & 32 \\
\hline $\begin{array}{l}\text { Electric bicycles are a “cheat" and are not a healthy transportation } \\
\text { tool, because they require less physical effort }\end{array}$ & 14.4 \\
\hline Other & 8.3 \\
\hline
\end{tabular}

* Frequency is shown for each reason as a percentage of the subtotal. 


\subsection{Knowledge of the Regulations for EBs}

To what extent pupils know the regulations for EBs? In regard to pupils' knowledge of the legal speed regulations for EBs, $63 \%$ of the participants knew that $25 \mathrm{k} / \mathrm{h}$ is the legal speeding limitation, while the rest either did not know (14\%) or got it wrong (23\%). However, $17 \%$ indicated a higher than legal speed as being allowed, raising the concern of tacit tendency for risky behavior (Figure 7).

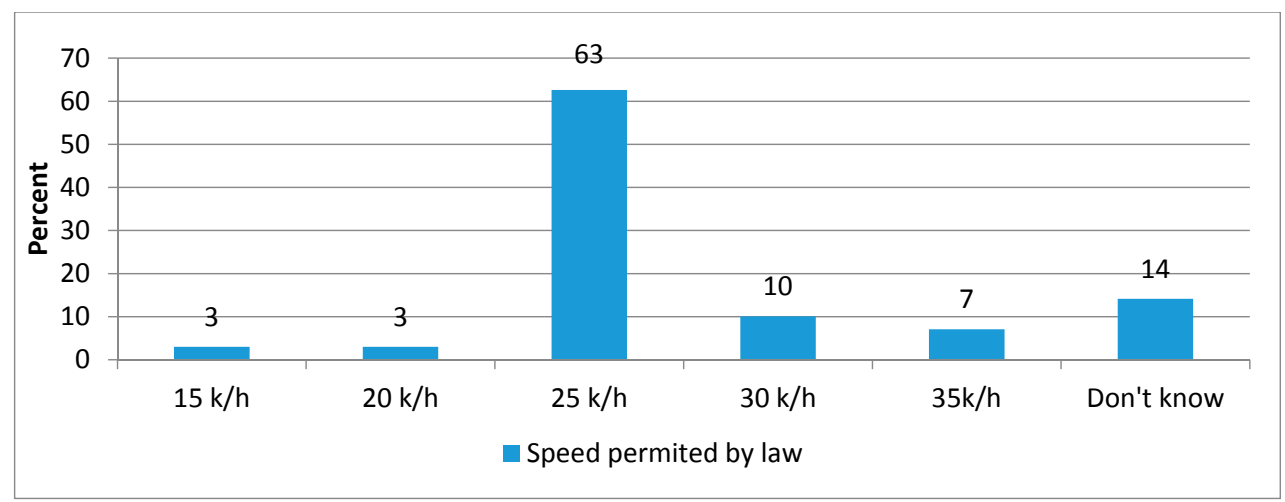

Figure 7. Legal speed limit for EBs.

Legal maturity was another regulatory aspect that was examined. As shown in Figure 8, 89\% of the teens were aware of the minimum legal age for riding an EB. Despite this fact, the results of the current study show that approximately $28 \%$ of the participant indicated that they rode EBs before being 16.

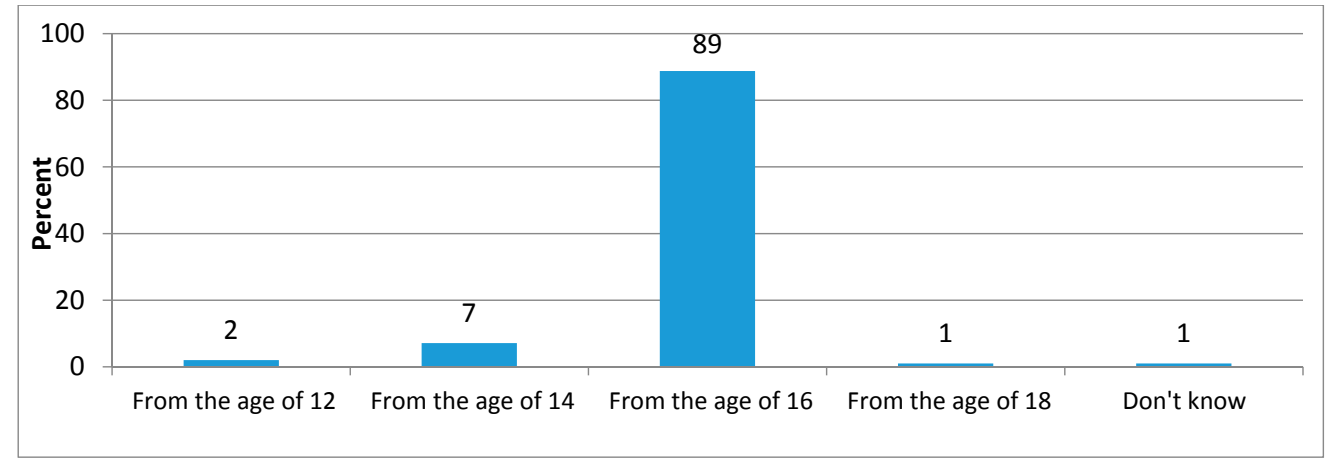

Figure 8. Minimum legal age for riding EBs.

Most pupils are not familiar with helmet laws, and assume that all EB riders are mandated to wear a helmet (Figure 9). However, according to the Israeli law only riders over 18 years old must wear a helmet while cycling. It is interesting to note that most of the children heard of the legal status of helmets from fellow peers, and not from more typical authority figures, such as their parents or teachers (Figure 10). This finding is of special interest when considering policy moves concerning children and safe behavior. 


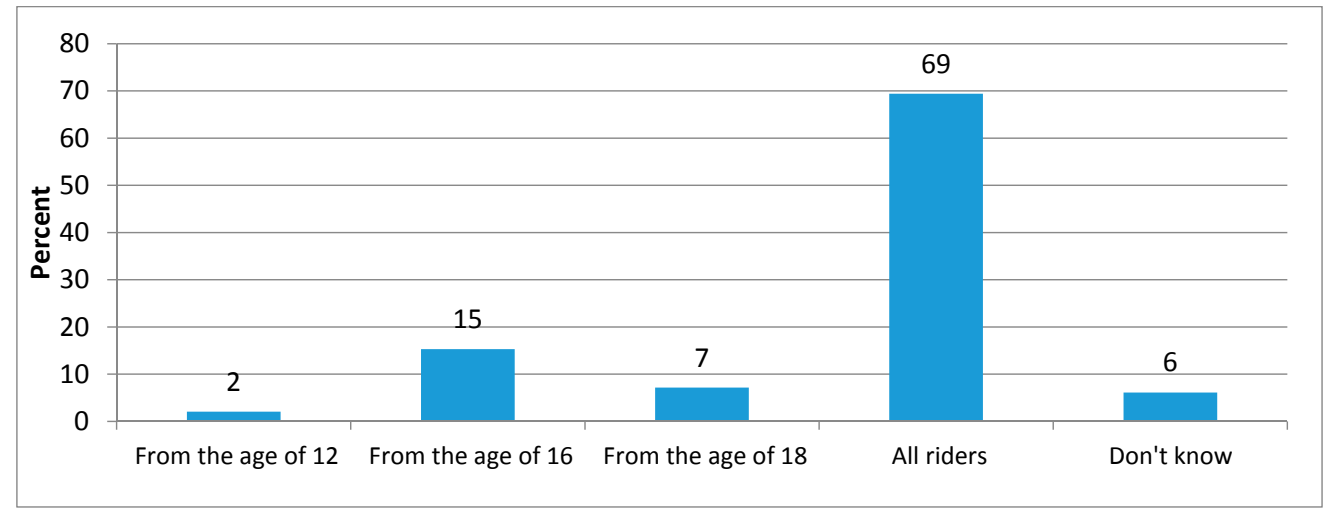

Figure 9. Who is legally obligated to wear a helmet while riding an EB?

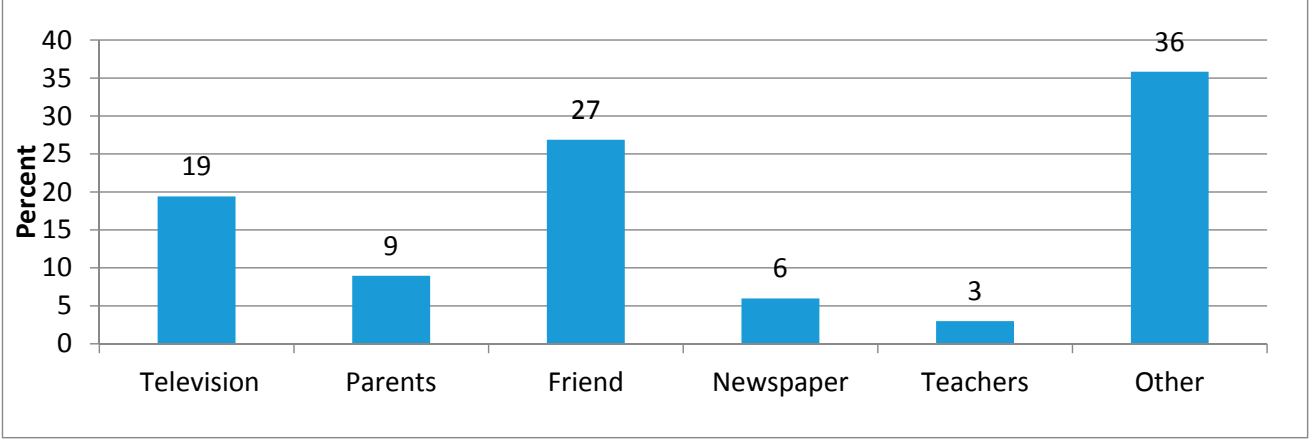

Figure 10. Distribution according to the source of the information.

This finding is consistent with the previous two, indicating that though most teens believe they are legally obliged to wear helmets $73 \%$ have admitted they did not wear helmets while riding EBs. Thus raising the question of whether knowing the law is sufficient in order to motivate safe behavior.

As shown in Figure 11 about a third of EB riders are not familiar with the law regarding where it is permissible to ride EBs.

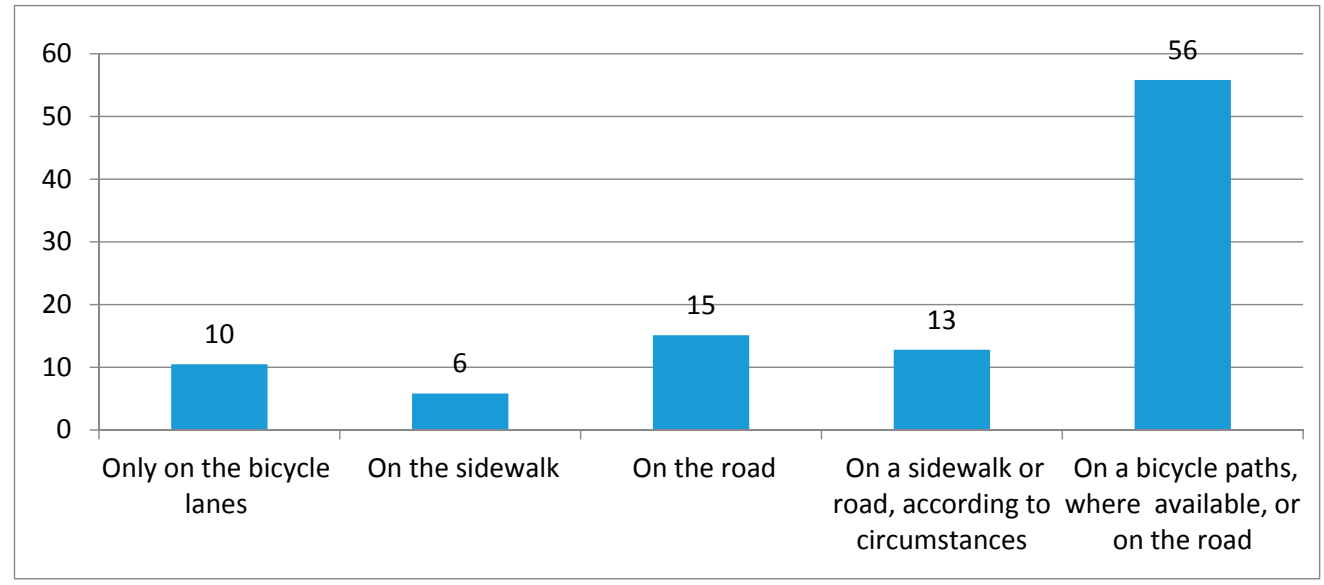

Figure 11. According to the law, where is it permissible to ride EBs?

\subsection{Safety Measures}

Figure 12 shows the distribution of the pupils when asked about the safety measures they take before riding EBs. More than one third of all pupils rode their EBs without reflectors or functioning lights. 


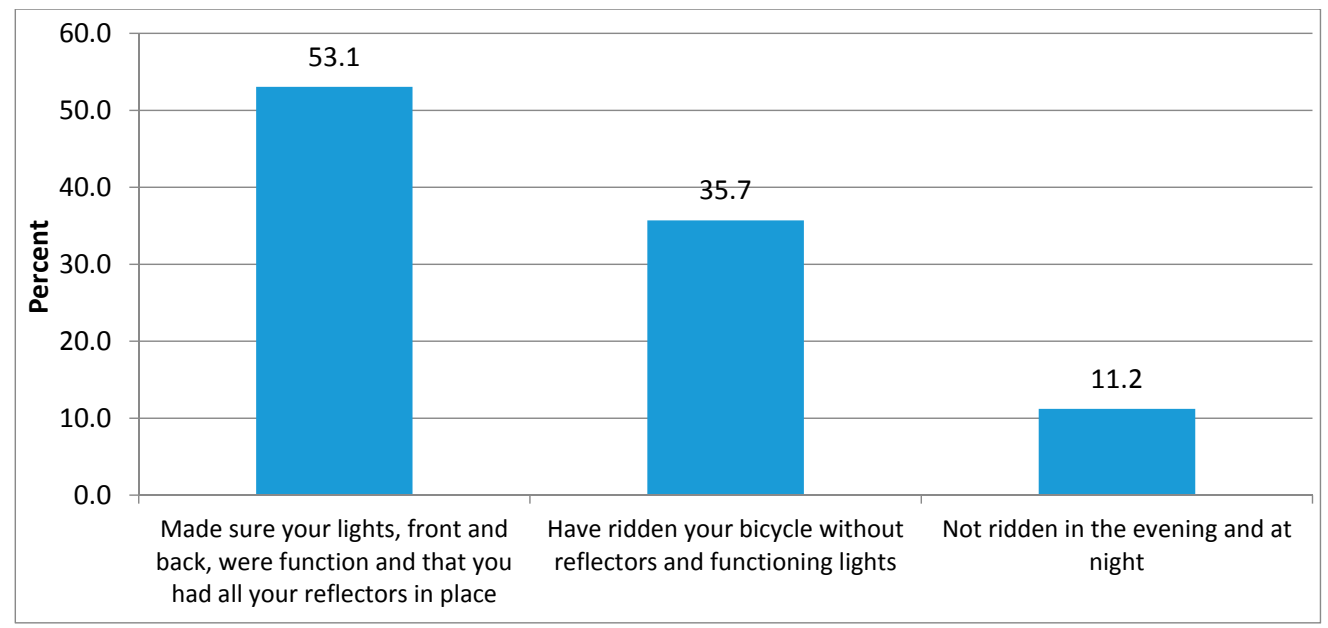

Figure 12. Safety measure when riding EBs.

It is possible to deduce from the data presented in Figure 13 that young EB users have been involved in various dangerous behaviors. More than a third of the EB users have run red lights, while riding amongst pedestrians, riding against traffic, and riding in between the lines have a more or less similar share of approximately $21 \%$.

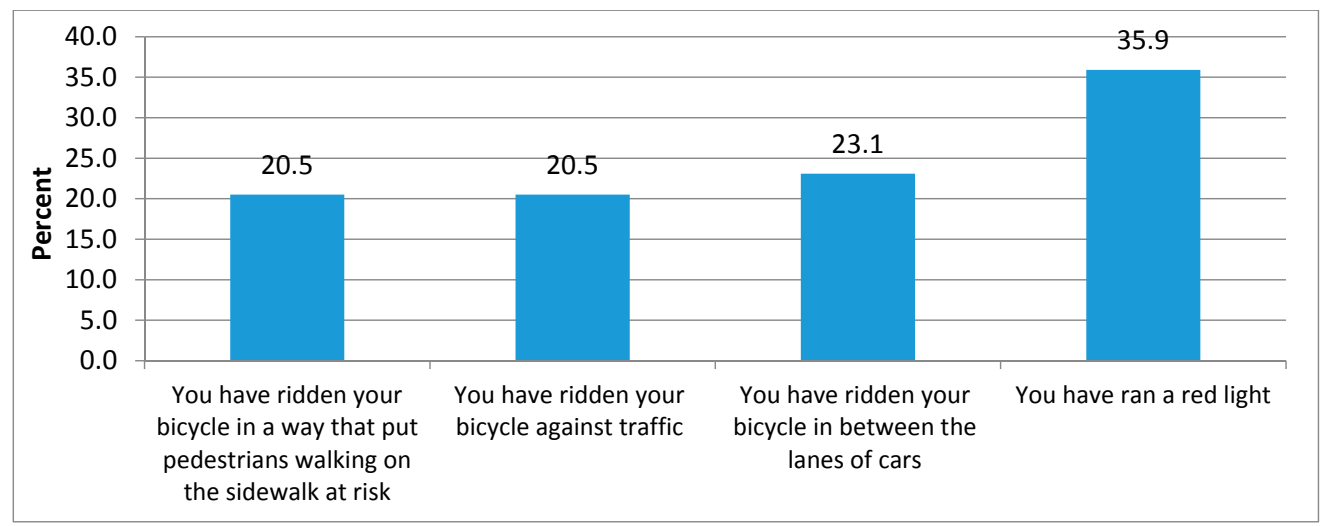

Figure 13. Dangerous behaviors in the past month.

The pupils were asked whether they and their friends follow the legal regulation for speed capping. As shown in Figure 14 the majority of EB riders are capable of speeds above the legal limit, a finding that may add to the understanding of the rise in injuries. Another aspect is that the increase in speed can also lead to a higher exposure to road risks.

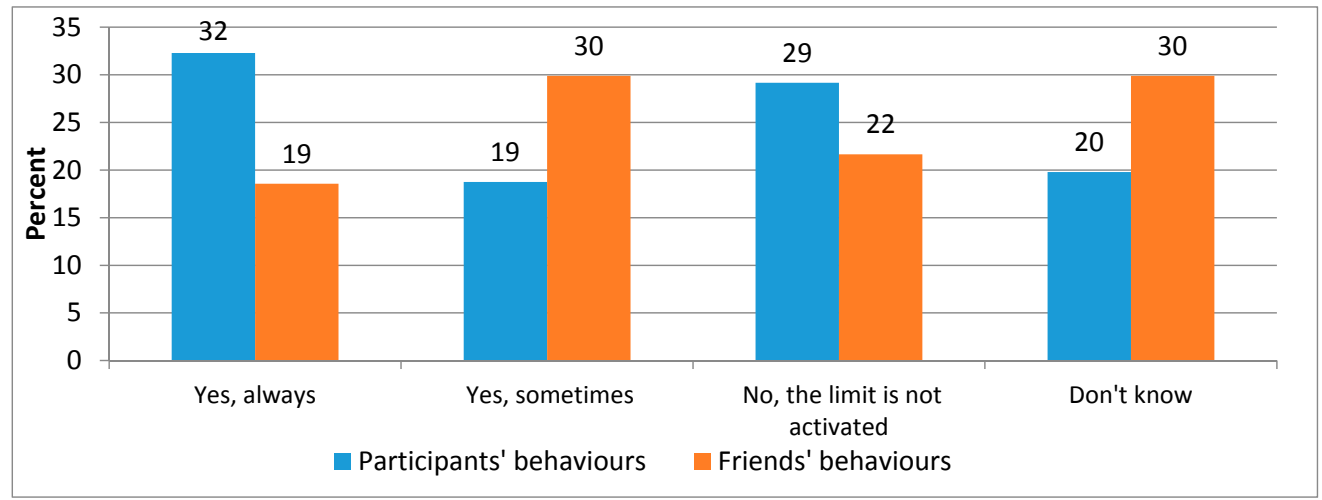

Figure 14. Distribution of EBs users and their friends by limiting the operation of the electric motor. 
As could be expected, the behavior of the EBs riders' friends was quite similar and the majority of the friends are capable of speeding above the legal limit. This clearly indicates some degree of peer group agreement on riding norms. It is possible to surmise from this finding that peer pressure plays a part in decision making. We also conducted a Pearson correlation test in order to assess the relationship between the two variables. The analysis shows that there is a positive correlation between EBs users' behavior and their friends' behaviors ( $r s=0.49 ; p=0.000)$.

\subsection{Perceived Risks}

Figure 15 presents the main perceived risks associated with riding EBs amongst EB riders. Pupils were given the option to choose more than one answer. According to the figure, the dangerous behavior of vehicle drivers on the road is the main risk. While the second risk is riding on a narrow sidewalk, followed by distracted and careless pedestrians. In addition, most EB riders believe they were in danger while riding their EB. Sixty-seven percent agreed with the statement that in recent months, they were in a situation of "almost an accident". This finding is consistent with the rise in injuries related to EBs road crashes.

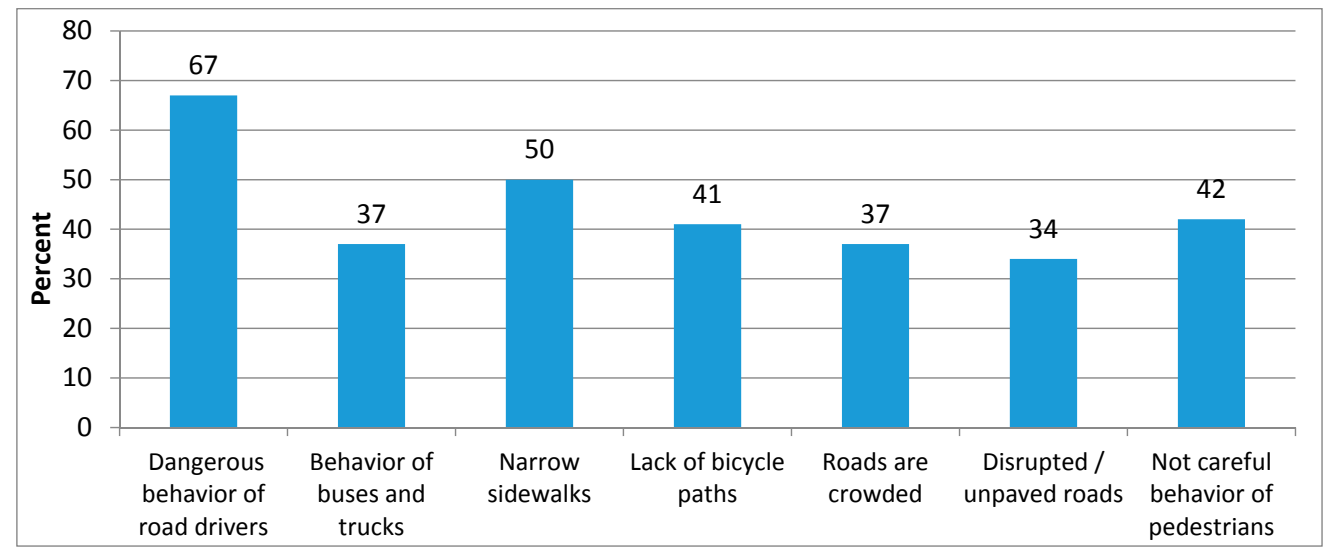

Figure 15. Main risks associated with riding EBs.

\subsection{Attitudes and Norms Related to Riding EBs}

We also attempted to reveal the degree of agreement with statements reflecting attitudes and norms related to riding EBs. Table 3 presents the degree of agreement with statements reflecting attitudes and norms related to riding EBs by gender, ranging from 1 (completely disagree) to 5 (strongly agree). For the comparison between boys and girls, the Pearson Chi-Square test was used.

Table 3 shows that more than $60 \%$ of EB riders completely disagree that experienced riders can assess when it is possible to overlook certain traffic laws in order to ensure a smooth riding experience. At the same time, $18 \%$, which is hardly dismissible, strongly agree.

As can be expected, the majority of EBs don't use a helmet, while only $20 \%$ completely agree with using a helmet at all times.

Where to ride the EB is another issue relevant to the assessment of riders' attitudes to risky behaviors. More than $60 \%$ prefer riding EB on sidewalks, since riding on the road is dangerous. Furthermore, 50\% believe that as long as they are attentive to their surroundings, riding their EB's on the sidewalk can be regarded as safe. When asked about doing bike-tricks, half of the EB users agreed that it is not considered risky behavior, as long as one knows what they are doing. Inquiring into their subjective norms, half the pupils agreed that people who they respected and valued their opinion did not necessarily always ride according to the law. In addition, more than 70\% of the pupils riding EBs agreed that most of their friends who rode EBs also did not wear helmets on every ride. These results show that teen's risky EB riding behaviors are influenced by the degree of obedience to the law in the environment in which they live. 
Table 3. Attitudes and norms of pupils riding EBs by gender.

\begin{tabular}{|c|c|c|c|c|c|c|}
\hline Attitudes & Gender & $1 *$ & 2 & 3 & $4 * *$ & $p$-Value \\
\hline \multirow{3}{*}{$\begin{array}{l}\text { An experienced cyclist can assess when it } \\
\text { is possible to overlook certain traffic laws } \\
\text { in order to ensure a smooth riding } \\
\text { experience }\end{array}$} & Entire sample & 33.3 & 30.0 & 18.9 & 17.8 & \\
\hline & Boys & 25.8 & 30.3 & 22.7 & 21.2 & \multirow{2}{*}{0.024} \\
\hline & Girls & 56.5 & 30.4 & 4.3 & 8.8 & \\
\hline \multirow{3}{*}{ I always use a helmet, even on short rides } & Entire sample & 49.4 & 19.1 & 11.2 & 20.2 & \\
\hline & Boys & 53.8 & 16.9 & 7.8 & 21.5 & \multirow{2}{*}{0.257} \\
\hline & Girls & 39.2 & 21.7 & 21.7 & 17.4 & \\
\hline \multirow{3}{*}{$\begin{array}{l}\text { I prefer riding my bicycle on sidewalks, } \\
\text { because riding on the road is dangerous }\end{array}$} & Entire sample & 16.9 & 20.2 & 31.5 & 31.5 & \\
\hline & Boys & 16.9 & 18.5 & 30.8 & 33.8 & \multirow{2}{*}{0.918} \\
\hline & Girls & 17.4 & 21.7 & 34.8 & 26.1 & \\
\hline \multirow{3}{*}{$\begin{array}{l}\text { As long as the cyclist is attentive to their } \\
\text { surroundings, there is no imminent risk in } \\
\text { riding on the sidewalk }\end{array}$} & Entire sample & 24.7 & 24.7 & 27.0 & 23.6 & \\
\hline & Boys & 23.1 & 26.2 & 20.0 & 30.8 & \multirow{2}{*}{0.019} \\
\hline & Girls & 26.1 & 21.7 & 47.8 & 4.3 & \\
\hline \multirow{3}{*}{$\begin{array}{l}\text { As long as one knows what they are doing, } \\
\text { there is no real risk in doing bike-tricks }\end{array}$} & Entire sample & 56.8 & 22.7 & 9.1 & 11.4 & \\
\hline & Boys & 56.1 & 21.2 & 10.6 & 12.1 & \multirow{2}{*}{0.786} \\
\hline & Girls & 57.1 & 28.6 & 4.8 & 9.5 & \\
\hline \multirow{3}{*}{$\begin{array}{l}\text { I am capable of riding on the sidewalk } \\
\text { without hitting passersby or other cyclists, } \\
\text { but I am not convinced that other cyclists } \\
\text { have the same abilities }\end{array}$} & Entire sample & 9.1 & 15.9 & 36.4 & 38.6 & \\
\hline & Boys & 9.2 & 18.5 & 30.8 & 41.5 & \multirow{2}{*}{0.392} \\
\hline & Girls & 9.1 & 9.1 & 50.0 & 31.8 & \\
\hline \multicolumn{7}{|l|}{ Subjective norms } \\
\hline \multirow{3}{*}{$\begin{array}{l}\text { People whom I respect and value their } \\
\text { opinion, and who also ride e-bicycles, } \\
\text { always ride according to the law }\end{array}$} & Entire sample & 20.9 & 35.2 & 28.6 & 15.4 & \\
\hline & Boys & 21.5 & 29.2 & 35.4 & 13.8 & \multirow{2}{*}{0.144} \\
\hline & Girls & 20.8 & 50.0 & 12.5 & 16.7 & \\
\hline \multirow{3}{*}{$\begin{array}{l}\text { Friends who ride e-bicycles don't wear } \\
\text { helmets on every ride }\end{array}$} & Entire sample & 14.4 & 14.4 & 24.4 & 46.7 & \\
\hline & Boys & 18.5 & 13.8 & 24.6 & 43.1 & \multirow{2}{*}{0.430} \\
\hline & Girls & 4.3 & 17.4 & 26.1 & 52.2 & \\
\hline
\end{tabular}

${ }^{*}$ Completely disagree; ${ }^{* *}$ strongly agree.

In regards to differences in attitudes and norms of pupils riding EBs between boys and girls, Table 3 shows that except for two factors no statistically significant relationship was found between gender and inclinations towards risky EB riding behaviors. As a rule, girls indicated less risky behavior than boys. Girls diverged significantly from boys, in disagreeing with the statement that an experienced cyclist can assess when it is possible to overlook certain traffic laws in order to ensure a smooth riding experience. Only $9 \%$ of the girls completely agreed with this statement, in comparison with $21 \%$ of the boys. In contrast, $56 \%$ of all girls completely disagreed with this statement compared with a $26 \%$ disagreement among the boys. Another factor indicating girls' reluctance to participate in risky EB riding behavior, was that only $5 \%$ completely agreed with the statement that as long as the cyclist is attentive to their surroundings, there is no imminent risk in riding on the sidewalk, compared to approximately one third of all boys completely agreeing with this statement. In regards to subjective norms, no significant differences were found between boys and girls.

By using Pearson and Chi-Square test analyses, no correlation between age (less than 16 and over 16) and attitudes and subjective norms were found. In addition, no correlation between the economic measures and attitudes and subjective norms were found.

\subsection{Correlation between Risky Behaviors and Attitudes and Norms}

Using a Pearson Correlation Test, we found a positive correlation between wearing helmets and believing that an experienced e-cyclist can assess when it is possible to overlook certain traffic laws 
in order to ensure a smooth riding experience $(p=-0.002)$. Similarly, but at a 0.1 level of confidence, a positive and significant correlation was found between subjective norms and wearing helmets. Pupils who agreed with the statement that people whom they respected and valued their opinion, and who also rode e-bicycles, always rode according to the law were more likely to wear helmets $(p=0.07)$. In contrast, pupils who claimed that their friends didn't obey the law nor wore a helmet while riding e-bicycles were less likely to wear a helmet $(p=-0.09)$.

It was interesting to examine to what extent attitudes held by EB users affected the likelihood to be involved in an almost accident situation. EB users who believe that an experienced cyclist can assess when it is possible to overlook certain traffic laws in order to ensure a smooth riding experience, were more likely to be involved in an almost accident situation $(p=0.086)$. While EB users who believe that as long as they know what they are doing, there is no real risk in bike-tricks are less likely to be involved in an 'almost accident' $(p=0.036)$. An explanation for this supposedly counterintuitive negative correlation, maybe that experience informs on reality, thus participating in a chosen risky behavior may promote safe behavior in other contexts in which one might have less personal control.

In addition, a positive relationship was found between a law respecting the social environment and being the perceived likelihood of being involved in an almost accident. The more EB riders agreed with the statement that people whom they respect and value their opinion, and who also ride e-bicycles, always ride according to the law, the less likely they were to perceive themselves as being involved in a situation that could be defined as almost an accident $(p=0.023)$.

\section{Discussion}

Being aware of the growing phenomenon of using e-bicycles by youngsters in Israeli towns, with their seemingly dangerous behaviors and already negative implications on road traffic injury, an opinion survey of teen e-cyclists was conducted. The existing international literature is not extensive, and mostly refers to adults, thus the survey aimed to record and analyze characteristics, behaviors, and perceptions concerning EB. The study focused on students, between 14-18 years old, studying in the 9-12th grades from Israel's central region, where e-cycling in particular and cycling in general are widespread.

Our results show that $33 \%$ of active EB users were younger than 16 . Nonetheless, teens aged 16 or older were more likely to ride EB than those younger than 16. Johnson and Rose [12], offer similar results showing that boys are much more likely to ride EB than girls.

The introduction of EB changes travel behaviors. Consistent with Cherry and Cervero, MacArthur et al., and Fyhri and Fearnley [9-11], our results show that having EBs increases the number of trips and the number of destinations teens frequent. Moreover, EBs were found to be the most commonly used mode of transportation for all destinations, while visiting friends and commuting to school were overall the most popular destinations. These findings are consistent with Astegiano et al. [28] who showed that EBs are the preferred mode of transportation for all purposes, except for "general shopping".

Unsurprisingly, our results show that the two most commonly voiced reasons for using EBs were travelling to new destinations without being dependent on others, mainly parents, and commuting independently to school. These findings reflect the needs and preferences of the teenagers [29]. According to Schlossberg et al. [30] during recent decades the US has witnessed a substantial drop in the share of children and teens choosing to cycle and/or walk, from $49 \%$ to $14 \%$. It is fair to surmise that children have become less independent, while parents' daily activity has become more complex, especially for women [30]. On the one hand, shifting people from cars to more sustainable modes of transport can help reduce many transportation and health challenges, including traffic safety, traffic congestion, air pollution, and physical inactivity [31,32]. On the other hand, shifting people from cars to EBs, and in our case the increasing in the use of EBs among teenagers, greatly increases the exposure to bicycle accidents [33,34]. 
Where EBs are commonly used reveals how the perception of a phenomenon impacts the behavior related to the phenomenon. The results of the study show that only one third of the EB riders preferred the road, while over half of the participants preferred riding on bicycle-paths and if there were none then they preferred pedestrian sidewalks. It is worthwhile to note that riding on the road is permitted by law. Morgenstein [35] indicated the same when emphasizing the danger of EB riders being mostly children and youth riding on sidewalks, often riding against existing traffic regulations. This can be seen as a direct result of the high risk perceived by teens riding near motorized vehicles. Teens riding EBs, who were asked about the main risks associated with riding EBs, indicated drivers' dangerous behavior as the main risk.

A substantial percentage of the participants were not familiar with the limitations set in the law. The majority did not know there was an age group for which it was legally mandated to wear a helmet. More than one third of the teens did not know the legal speeding limitation and when asked, approximately one fifth indicated a higher than legal speed. This raises the concern of a tacit tendency for risky behavior. It is interesting to note that most of the children were familiar with the existence of legal regulations on helmets concerning age and speed. However, this was a result of word of mouth amongst peers, rather than from more typical authority figures, such as their parents or teachers. This finding is of special interest when considering policy related to children and safe behavior.

Furthermore, most teens choose not to wear helmets when riding EBs, and more than one third of all pupils ride without reflectors or functioning lights. This result is consistent with the findings of Colleen M Davison [36], who examined national patterns in bicycle ridership and bicycle helmet use among Canadian youth. The study results showed that only about a quarter of young Canadian cyclists wear a bicycle helmet at all times. Indeed, $43 \%$ of the cyclists in our study reported that they never wore a helmet. Wu et al. [37] showed that $56 \%$ of cyclists crossed intersections on red lights, similarly the results of the current paper show that more than one third of EBs users have run red lights. These findings highlight the question of whether a knowledge of the law is sufficient to motivate safe behavior.

The perceptions related to the use of EBs are also organized around one's perception of risk. The findings show that most EB riders believe they have been in a life-threatening situation. Approximately $66.7 \%$ admitted to having been in a situation of "almost an accident" in a period of a few months prior to the study. This finding is consistent with the rise in injuries related to EB road crashes [26].

As findings have shown [38], when close friends or relatives own an EB, chances that a person will buy one for themselves are higher. Adding to Engelmoer's [39] findings that attitudes, habits, social and cultural influences determine the use of EB, our result show that peer pressure also plays a part in decision making, having a positive correlation between EBs users' behavior and their friends' behavior. In addition, risk perceptions influence EBs behaviors with those who perceived riding on the road as being very dangerous preferring to ride on sidewalks.

Finally, electric bicycles have become a popular trend amongst teens and youth in Israel, offering them another venue for accruing symbolic prestige with peers. In light of the shape the phenomenon is taking and the results of the current study, it is safe to say that the use of EBs in Israel, will continue and become even more prevalent. This is true despite new laws regulating the use of EBs, setting a minimum age of 16 , as well as various restrictions on speed and safety. Though these steps are intended to regulate EB's in order to insure the greater good, it seems that the lack of appropriate infrastructure, i.e., bicycle paths and traffic ordinances, leaves the users at the throes of chance. This on the one hand raises the risk factor of using EBs, and on the other it leaves teens and youth to cope with mixed-use environments that cater to cars, but does not take e-cycling requirements into account. Thus, many of the teens end up adopting dangerous riding behaviors as a result of their fear of being involved in an accident. 


\section{Conclusions}

It is fair to say that nowadays there is a consensus regarding encouraging the public, especially youth, to be independent and take responsibility for their personal actions. When thinking of transportation policy, sustainability often takes the front stage. In the case of the use of EBs by teens and youth in Israel there seems to be a paradox. As a mode of transportation, it is practically ideal, since it is convenient for short distance travels and does not require special training. However, the absence of appropriate infrastructure is met with regulations that either discourage people from acquiring EBs by raising fears and concerns regarding the safety of the riders and their surroundings, or encourages the users to forge their own idiosyncratic sensibilities to cope with a disorganized mixed-use space.

When examining adults' and youth's perceptions regarding the use of EBs there is a consensus that bicycle paths and the integration of appropriate traffic infrastructure would benefit everyone. For the users the utility of EB's is more important than the prestige that might be gained by owning one. For parents and onlookers, the lack of infrastructure and weak enforcement of regulations make EB's a nuisance and a transportation wildcard perceived to place anyone that has to contend with them in danger. This raises the question whether the quick fix, i.e., toughening regulations and their enforcement, is truly practical and won't only lead to the vilification of teens and youth, eventually transforming them into potential delinquents?

We recommend that a combination of road safety education and training, as well as an investment in the improvement of existing infrastructure improvement, as the best way to tackle this new and rapidly growing phenomenon. This approach is in line with the main goals set today by urban planning professionals, who are protecting the environment while also protecting the lives of our children.

Author Contributions: Conceptualization, W.E. and V.G.; Methodology, W.E.; Software, W.E.; Validation, W.E. and V.G.; Formal Analysis, W.E. and V.G.; Investigation, W.E.; Resources, W.E. and V.G.; Data Curation, W.E.; Writing-Original Draft Preparation, W.E.; Writing-Review \& Editing, W.E. and V.G; Visualization, W.E.; Supervision, W.E.; Project Administration, W.E.; Funding Acquisition, W E.

Funding: This research was funded by the Ministry of Science, Technology and Space, Israel, grant number 3-12476. The APC was funded by Shamoon College of Engineering, Israel.

Acknowledgments: This research was supported by the Ministry of Science, Technology and Space, Israel.

Conflicts of Interest: The authors declare no conflicts of interest

\section{References}

1. Fishman, E.; Cherry, C. E-bikes in the mainstream: Reviewing a Decade of Research. Transp. Rev. 2016, 36, 72-91. [CrossRef]

2. Dozza, M.; Werneke, J.; Mackenzie, M. E-BikeSAFE: A Naturalistic Cycling Study to Understand How Electrical Bicycles Change Cycling Behaviour and Influence Safety. In Proceedings of the International Cycling Safety Conference 2013, Helmond, The Netherlands, 20-21 November 2013.

3. Zap.co.il. Available online: https://www.zap.co.il/models.aspx?sog=s-bycicle\&db125911=4793603\& orderby=price_desc (accessed on 28 October 2018).

4. Konor-Atias, E.; Liberman, A. Employees, Employers, and The National Income Cake: 2016 Report; [ [ובדים, 2017.

5. Auto.co.il. Available online: https://www.auto.co.il/article/129669-local-news (accessed on 28 October 2018).

6. Israel Electrical Company. Available online: https://www.iec.co.il/homeclients/pages/tariffs.aspx (accessed on 20 November 2018).

7. The True Costs of Owning and Using an Electric Bike. Available online: https:/ /electricbikereview.com/forum/ threads/the-true-costs-of-owning-and-using-an-electric-bike.22739/ (accessed on 20 November 2018).

8. Rose, G. E-bikes and urban transportation: Emerging issues and unresolved questions. Transportation 2012, 39, 81-96. [CrossRef]

9. Cherry, C.; Cervero, R. Use Characteristics and mode choice behavior of electric bike users in China. Transp. Policy 2007, 14, 247-257. [CrossRef] 
10. Fyhri, A.; Fearnley, N. Effects of e-bikes on bicycle use and mode share. Transp. Res. Part D Transp. Environ. 2015, 36, 45-52. [CrossRef]

11. MacArthur, J.; Dill, J.; Person, M. E-Bikes in the North America: Results from an online survey. Transp. Res. Rec. J. Transp. Res. Board 2014, 2468, 123-130. [CrossRef]

12. Johnson, M.; Rose, G. Electric bikes-cycling in the New World City: An investigation of Australian electric bicycle owners and the decision making process for purchase. In Proceedings of the Australasian Transport Research Forum 2013, Brisbane, Australia, 2-4 October 2013.

13. Popovich, N.; Gordon, E.; Shao, Z.; Xing, Y.; Wang, Y.; Handy, S. Experiences of electric bicycle users in the Sacramento, California area. Travel Behav. Soc. 2014, 1, 37-44. [CrossRef]

14. Traffic Regulations. Available online: https:/ /www.nevo.co.il.law_htm/Law01 (accessed on 16 June 2016).

15. Janco, A. The Electric Bicycle Threat on the Rise-And Noone is Taking Responsibility for it [החשמליים מתגברתואין לקיחת אחריות סכנת האופניים.]. Available online: https://www.ynet.co.il/articles/0,7340, L-5286271,00.html (accessed on 28 October 2018).

16. Posk, H. A Threat Named Electric Bicycles: A Sharp Rise in Casualties [ סכנה ושמה אופניים חשמליים: זינוק חד במספר ההרוגים]. Available online: https://www.ynet.co.il/articles/0,7340,L-4857777,00.html (accessed on 28 October 2018).

17. Even, Y. The Threat of Electric Bicycles [סכנת האופניים החשמליים]. Available online: https://www.mako.co.il/ news-channel2/Channel-2-Newscast-q3_2018/Article-28ae18adfe11661004.htm (accessed on 28 October 2018).

18. Scaramuzza, G.; Uhr, A.; Neimann, S. E-Bikes im Strassenverkehr-Sicherheitsanalyse; Bfu-Beratungsstelle fur Unfallverhutung: Bern, Germany, 2015.

19. Langford, B.C.; Chen, J.; Cherry, C.R. Risky riding: Naturalistic methods comparing safety behavior from conventional bicycle riders and electric bike riders. Accid. Anal. Prev. 2015, 82, 220-226. [CrossRef] [PubMed]

20. Du, W.; Yang, J.; Powis, B.; Zheng, X.; Ozanne-Smith, J.; Bilston, L.; Wu, M. Understanding on-road practices of electric bike riders: An observational study in a developed city of China. Accid. Anal. Prev. 2013, 59, 319-326. [CrossRef] [PubMed]

21. Yang, X.; Huan, M.; Abdel-Aty, M.; Pemg, Y.; Gao, Z. A hazard-based duration model for analyzing crossing behavior of cyclists and electric bike riders at signalized intersections. Accid. Anal. Prev. 2015, 74, 33-41. [CrossRef] [PubMed]

22. Dozza, M.; Piccinini, G.F.B.; Werneke, J. Using naturalistic data to assess e-cyclist behavior. Transp. Res. Part F 2016, 41, 217-226. [CrossRef]

23. Petzoldt, T.; Schleinitz, K.; Heilmann, S.; Gehlert, T. Traffic conflicts and their contextual factors when riding conventional vs electric bicycles. Transp. Res. Part F 2017, 46, 477-490. [CrossRef]

24. Schepers, J.P.; Fishman, E.; den Hertog, P.; Klein Wolt, K.; Schwab, A.L. The safety of electrically assisted bicycles compared to classic bicycles. Accid. Anal. Prev. 2014, 73, 174-180. [CrossRef] [PubMed]

25. Gertner Institute. Electric Bicycles and Scooters Injury. 2014. Available online: http:/ /www.gertnerinst.org. il/health_policy/trauma/trauma_research/706.htm (accessed on 13 November 2018).

26. Gertner Institute. A Position Paper of the National Center for Trauma and Emergency Medicine Research on the Subject of Electric Bicycles and Scooters Injury; Gertner Institute: Tel Hashomer, Israel, 2015.

27. Ajzen, I.; Fishbein, M. Attitude-behavior relations: A theoretical analysis and review of empirical research. Psychol. Bull. 1977, 84, 888-918. [CrossRef]

28. Astegiano, P.; Tampere, C.M.J.; Beck, C. A preliminary analysis over the factors related with the possession of an electric bike. Transp. Res. Procedia 2015, 10, 393-402. [CrossRef]

29. Elias, W.; Katoshevski-Cavari, R. The role of socio-economic and environmental characters in school commuting behavior: A comparative study of Jewish and Arab groups in Israel. Transp. Policy 2014, 32, 79-87. [CrossRef]

30. Schlossberg, M.; Greene, J.; Phillips, P.O.; Johnson, B.; Parker, B. School trips: Effects of urban form and distance on travel mode. J. Am. Plan. Assoc. 2006, 72, 337-346. [CrossRef]

31. Elias, W.; Benjamin, J.; Shiftan, Y. Gender Differences in Activity and Travel Behavior in the Arab World. Transp. Policy 2015, 44, 19-27. [CrossRef]

32. MacArthur, J.; Dill, J.; Person, M. Electric bikes in the North America: Results of an online survey. Transp. Res. Rec. J. Transp. Res. Board 2014, 2468, 123-130. [CrossRef]

33. Yang, C.-W.; Ho, Y.-L. Assessing carbon reduction effects toward the mode shift of green transportation system. J. Adv. Transp. 2016, 50, 669-682. [CrossRef] 
34. Sun, Y.; Mobasheri, A.; Hu, X.; Wang, W. Investigating Impacts of Environmental Factors on the Cycling Behavior of Bicycle-Sharing Users. Sustainability 2017, 9, 1060. [CrossRef]

35. Morgenstein, D. Electric bikes-A transportation disaster or an urban solution? Journal of Managerial and Strategic Thinking, 13 June 2016.

36. Davison, C.M.; Torunian, M.; Walsh, P.; Thompson, W.; McFaull, S.; Pickett, W. Bicycle helmet use and bicycling-related injury among young Canadians: An equity analysis. Int. J. Equity Health 2013, 12, 48. [CrossRef] [PubMed]

37. Wu, C.; Yao, L.; Zhang, K. The red-light running behaviour of electric bike riders and cyclists at urban intersections in China: An observational study. Accid. Anal. Prev. 2012, 49, 186-192. [CrossRef] [PubMed]

38. MacArthur, J.; Kobel, N. Regulations of E-bikes in North America, a Policy Review; Portland State University: Portland, OR, USA, 2014.

39. Engelmoer, W. The E-bike: Opportunities for Commuter Traffic. The Potential of Using Electric Bicycles and Scooters in Commuting Traffic in Relation to the Accessibility and Quality of the Local Environment of a Compact Dutch city. Master's Thesis, University of Groningen, Groningen, The Netherlands, 2012.

(C) 2018 by the authors. Licensee MDPI, Basel, Switzerland. This article is an open access article distributed under the terms and conditions of the Creative Commons Attribution (CC BY) license (http://creativecommons.org/licenses/by/4.0/). 